\title{
PSYCHOLOGY
}

\section{COMMUNICATIVE COMPETENCE AS A MANDATORY COMPONENT OF THE PROFESSIONALISM OF SOCIAL PEDAGOGUE}

\author{
Candidate of Pedagogical Sciences Razmolodchykova I. V., \\ Ukraine, Kryviy Rih, Kryviy Rih State Pedagogical University
}

PhD in Psychology Shevyakova N. L., Director of the Higher Educational Institution

"Nikopol Pedagogical College" of Dnipropetrovsk Regional Council,

Ukraine, Nikopol, Higher Educational Institution "Nikopol Pedagogical College" of Dnipropetrovsk Regional Council

DOI: https://doi.org/10.31435/rsglobal_ws/30112019/6788

\section{ARTICLE INFO}

Received: 23 September 2019

Accepted: 14 November 2019

Published: 30 November 2019

\section{KEYWORDS}

communicative competence, social pedagogue,

social worker,

professional development, communication culture.

\begin{abstract}
The article is devoted to the study of the phenomenon of communicative competence of a social pedagogue. The relevance of the topic of the article is due to the social significance of the issue of the communicative competence formation in the future social pedagogue. The work emphasizes the importance of forming a professional culture of communication among students of higher educational institutions. It is noted that the effectiveness of communicative competence in the work of the future social pedagogue depends on a number of significant components: motives, goals, actions, operations, communication barriers that can change in the process of professional activity. It is noted that the profession of a social pedagogue is distinguished by a variety of functional, role, interpersonal and intergroup relationships. They are complex, ambiguous, closely intertwined, since they cover the social, psychological, moral, economic, legal and many other spheres of life. All this necessitates fluency in the language as a means of communication for future successful professional activities. It is proved that communicative competence is an important component of the professional development of the future social pedagogue and one of the most important components of his professional growth.
\end{abstract}

Citation: Razmolodchykova I. V., Shevyakova N. L. (2019) Communicative Competence as a Mandatory Component of the Professionalism of Social Pedagogue. World Science. 11(51), Vol.4. doi: 10.31435/rsglobal_ws/30112019/6788

Copyright: (C) 2019 Razmolodchykova I. V., Shevyakova N. L. This is an open-access article distributed under the terms of the Creative Commons Attribution License (CC BY). The use, distribution or reproduction in other forums is permitted, provided the original author(s) or licensor are credited and that the original publication in this journal is cited, in accordance with accepted academic practice. No use, distribution or reproduction is permitted which does not comply with these terms.

Formulation of the problem. To characterize the professionalism of a specialist, the concept of professional competence is now increasingly used. Various aspects of the problem of competence were studied by domestic and foreign psychologists and teachers: M. P. Vasilyeva, D. I. Dzvinchuk, V. A. Kazakov, T. N. Lebedynets, I. Lozova, A. K. Markova, L. A. Petrovska, V.V. Pylaev, L.P. Pukhovska, A. Sysoeva, A. V. Khutorskoy, Ya.V. Tsekhmister and others. Some questions of communicative competence were considered by A. I. Yeliseyev, T. N. Kalchenko, N. A. Kulik, V. A. Tyurina. But the matters of the features and ways of forming the communicative competence of a social pedagogy as a component of his professional competence have not been sufficiently studied.

Ukraine has a significant need for specialists in the specialty "Social pedagogy" who would be able to successfully implement modern tasks of social policy, to be fluent in new forms and methods 
of social and socio-pedagogical research, to skilfully use effective technologies of practical work with various categories of the population in practice [3].

The future professional activity of competitive specialists requires them to have not only professional skills, but also education related to intensive oral and written communication, provides for broad speech practice, requires accurate expression of concepts and categories in various areas of professional activity [5, p. 292].

Analysis of recent research and publications. Among domestic scientists, the problem of the content and structure of communicative competence is studied by teachers and psychologists N. Anikeyeva, N. Bibik, A. Bogush, A. Golovko, Yu. Emelyanov, Yu. Zhukov, M. Zabrotskyi, V. Zvyagintsev, I. Zimnya, V. Kan-Kalik, L. Koval, I. Kolesnikova, Yu. Krizhanska, A. Markova, L. Petrovska, T. Simonenko etc.

The basic material presentation. At the present stage of the society development, there is an increasing role of communication and the communicative competence of a person in the process of becoming the personality of a future specialist - a social pedagogue.

Communicative competence is the ability to establish and maintain the necessary contacts with other people.

Communicative competence includes the following components:

- sociability (the ability to establish and maintain the necessary contacts with other people);

- possession of meaningful information and the ability to operate it;

- Ability to partner and achieve mutual understanding.

An important component in the work of a social pedagogue is the ability to establish communication, that is, communicate effectively and freely.

Based on the idea of the unity of communication and activity (B. Ananyev, A. Leontyev, S. Rubinstein and others), communication is understood as the reality of human relations, which provides for any form of joint activity of people. That is, any form of communication refers to specific forms of joint activity. In addition, people do not just communicate in the course of performing certain functions. But they always communicate during the relevant activities. Therefore, an active person always communicates [7, p. 322].

Considering communication as one of the main varieties of human activity. B. Ananyev interprets it as a kind of fusion of the social and the individual in the social life of a person. He identified and traced the main directions of the communication impact on the formation of the human mental world and posed the problem of studying the dependencies that connect the external and internal characteristics with the manifestations of the psyche of the people participating in communication.

Communication is a necessary condition for any human activity, but at the same time having a common nature, we talk about activity only when this activity is social in nature, and not by external forms of existence. Therefore, it can be argued that any human activity is impossible without communication. So, communication is an important element of human activity [4, p. nine].

Communication is the exchange of messages, information that is submitted in the form of oral or written texts in the language that the interlocutors speak, and is carried out in speech acts of various forms (dialogue, polylogue, monologue). An indispensable participant in communication, in addition to the speaker, is the listener, real or imagined. Speech, therefore, is concrete speaking, spoken or written, as well as perception (listening or reading).

The purpose of communication is to achieve mutual understanding or ensure interaction. Clarifying the position of the interlocutor, achieving mutual understanding, ensuring interaction is an in-depth diagram of a communication strategy.

Communication applies to all spheres of a person's conscious activity, because a person is a social being who can live and act normally only in the midst of other people, with whom the individual enters into social structures and performs social functions.

Thus, communication is based on extremely important goals - mutual understanding and interaction and a powerful motive - the need for socialization. Without communication, the existence of society and, accordingly, the life of an individual is impossible. Of course, speech should also perform other functions, for example, cognitive (the function of cognition: the words contain knowledge of the world that we have accumulated), aesthetic (we may like the poem even irrespective of its content), etc. But these language functions are secondary, they are derivative from a communicative function or accompany it $[4, \mathrm{p}$. eleven $]$. 
It is undeniable that the quality of a person's social life largely depends on the nature of his communication with other people. To one degree or another, each person has a need for communication, forging social contacts. During communication, it is not only an exchange that takes place, but also an increase in knowledge, the transformation of the achievements of each participant in communication into their joint achievements. Therefore, it is through communication a person is trained and educated, assimilates various forms of social experience, norms and rules of behaviour, traditions and customs. At the same time, various traits and properties of the personality manifest themselves and are revealed in communication.

The culture of communication is a component of human culture and the social environment in which the interaction with their own kind. It reflects the value orientations, positions, social roles that the individual performs in society. The culture of communication determines the ways people interact in specific situations, based on norms, traditions, and the national identity of society.

The culture of communication depends not only on the personality, its communication capabilities, but also on the knowledge acquired by a person, the abilities and skills to establish contacts [2, p. 92].

Communication is one of the manifestations of the human essence, a personal form of social relations functioning. It reflects the objective need of people to live in society, to unite and cooperate with each other.

Communication is an integral part of human existence, an important prerequisite for the formation of a human as a social being, capable of coexistence with his own kind.

Communication culture is an integral part of the personality culture of a modern specialist in the social sphere (social pedagogue), characterizes its value orientations and normative communication paradigms, the content and essence of the moral and psychological qualities of communication subjects, methods, means, rules, forms of communication. The culture of communication contains a set of practical techniques, norms, rules of communication. So, the essence of communication culture is a system of internal resources necessary to create effective communication in a certain range of situations of interpersonal interaction.

The centre of the formation professional speech culture in a future specialist is his personality, so special attention should be paid to the humanization of the formation of a culture of professional communication among university students as part of their professional training.

Formation of a culture of professional communication among students of higher educational institutions as a holistic, inextricable, complex process requires the integration of various interrelated approaches, however, the most important of them is the humanization of the pedagogical process, closely associated with personality-oriented teaching and upbringing [1, p. 99].

N. Anikeyeva, A. Boyko, Yu. Vaskov, M. Zabrotskyi, I. Zaretska, V. Kirichek, V. Kushniruk, S. Maksimenko, L. Petrovska and others noted the importance of mastering communicative competence. And in our case, communicative competence is a component of the professional competence of a social pedagogue.

Ukrainian researchers, who studied the experience of the countries participating in the Bologna process, note that in Europe the efforts of representatives of almost 100 universities have already made an attempt to determine the basic competencies of specialists. 30 general competencies were selected from three categories: instrumental, interpersonal, and systemic.

Instrumental competences are those that include cognitive abilities (the ability to understand and use ideas and considerations), methodological abilities (the ability to understand and manage the environment, organize working hours, master the learning strategy, make decisions and solve problems); technological skills (skills related to the use of technology, computer skills and information management abilities); linguistic skills; communicative competencies.

Instrumental competencies include:

- ability for analysis and synthesis;

- ability to organize and plan;

- basic general knowledge;

- basic knowledge on the profession;

- communicative skills in the native language;

- elementary computer skills;

- skills in operating information (the ability to receive and analyze information from various sources); 
- ability to solve problems;

- ability to make decisions [2, p. 203].

Interpersonal competencies are individual abilities related to the ability to express feelings and form relationships with critical reflection and the ability to self-criticize, as well as social skills related to the processes of social interaction and cooperation, the ability to work in groups, and make social and ethical obligations. A set of interpersonal skills includes:

- ability to criticize and self-criticize;

- ability to work in a team;

- interpersonal skills;

- ability to work in an interdisciplinary team;

- ability to collaborate with experts in other subject areas;

- ability to perceive diversity and intercultural differences;

- ability to work in an international context;

- adherence to ethical values [3, p. 207].

System competencies are a combination of understanding, attitude and knowledge, which allows perceiving the correlation of constituents with each other and assessing the place of each component in the system, the ability to plan changes in order to improve the system and construct new systems. These include:

- ability to put knowledge into practice;

- research abilities;

- ability to learn;

- ability to adapt to new situations;

- ability to generate new ideas (creativity)

- ability for leadership;

- understanding of cultures and customs of other countries;

- ability to work autonomously;

- ability to develop projects and manage them;

- ability for initiative and entrepreneurship;

- responsibility for quality;

- desire for success [3, p. 211].

We are impressed by the opinion of L. Karpova, who notes that "the professional competence of the teacher, and in our case it can be safely asserted that it is a social pedagogue, is an integrated personal education based on theoretical knowledge, practical skills, significant personal qualities and experience that determine a high level of self-organization" .

The professional competence of a social pedagogue has no narrow professional boundaries, since he is required to constantly reflect on and solve the variety of social, psychological and other clients' problems.

One of the most important components of the professional competence of a social pedagogue is communication skills.

G. Ball, M. Boryshevskyi, M. Zabrotskyi, V. Kan-Kalik, Y. Kolominskyi, A. Leontyev and others considered the issue of communicative competence, giving it one of the leading roles in the formation of pedagogical skill. These researchers substantiated the phenomenon of pedagogical communication as an essential, in-depth characteristic of the pedagogical process, a type of professional communication, due to which a socio-psychological interaction between the process participants takes place.

The concept of "communication" is used in the scientific literature in different meanings: as an exchange of thoughts, feelings, experiences (L. Vygotskyi, S. Rubinstein); as one of the varieties of human activity (B. Ananyev, M. Kogan, A. Leontyev); as a specific social form of information communication (A. Ursun, L. Reznikov) as interaction, relations between subjects that are dialogical in nature (G. Andreyeva, V. Sokovin, Platonov) [5].

In psychology, pedagogical communication is often defined as the interaction of subjects of the pedagogical process, carried out by symbolic means and aimed at significant changes in the properties, states, behaviour and individual-semantic images of partners.

The founders of the theory of communication - L. Vygotskyi, A. Leontyev, A. Lurya, T. Akhutin (Ryabova) and others - consider communication as a kind of human activity as a whole, speech activity along with work, play, cognitive, etc. Vygotskyi and his followers consider that the most important components of the activity are: 
1) motive - the reason, the impetus for the beginning of speech activity. Motives for communication can be very diverse and apply to almost all areas of human life: physical, physiological, intellectual, spiritual;

2) goal - a conscious idea of the result of speech activity, which must be achieved in the process of communication. The goal is closely related to the motive of speech activity and affects its further course;

3 ) action - the implementation of something with a specific purpose, follows from a common goal;

4) operation - a method of performing a speech action. Operations are related to the conditions for achieving the goal (place, time, environment, situation, context, various internal and external influences, etc.).

Pedagogical communication is a complex and internally contradictory interweaving of perceptual, communicative, interactive components, subject-object and subject-subject forms, reproductive and productive, in-depth, personal and role-playing communication and the like.

It should be noted that in the professional activity of a social pedagogue, the subject-subjective nature of pedagogical communication is important. After all, as L. Petrovska notes, "the principle of its effective organization is the equality of psychological positions, mutual humanistic attitude, their interpenetration into the world of feelings and emotions, readiness to accept the interlocutor, interact with him [8, p. 78-79].

The main features of pedagogical communication on subject-subject ground are:

1. Personal orientation of the interlocutors - the willingness to see and understand the interlocutor; self-worthy attitude to another one. Considering the right of everyone to choose, we should not impose an opinion, but help the other choose their own way of solving the problem. In a specific situation, this can be done using various techniques.

2. Equality of psychological positions of interlocutors.

3. Penetration into the world of feelings and emotions, readiness to take the position of the interlocutor. This communication is under the laws of mutual trust, when partners listen to each other, share feelings, empathize.

4. Non-standard methods of communication, which is a consequence of avoiding the purely role position of a specialist [9].

The category that most closely reflects all aspects of the communicative activity of any person is communicative competence, which is understood in the framework of psychological and pedagogical theories as something more than just knowledge, experience, and mastery in communicative activity [4].

Under the communication skills of A.A. Kidron understands the creative use of various means of communication and ownership of orientation patterns in the process of interaction. Possession of communication skills, in his opinion, involves a sufficient level of automation of mental processes, the regulation of their behaviour occurs at the level of installation. The ability to communicate, in its consideration, involves a relatively autonomous communicative task with the targeted use of various communication skills.

In the structure of communicative and creative abilities, we distinguish two main components: intellectual-logical and emotional-heuristic abilities. The number of intellectual-logical communicative and creative abilities include:

- willingness to communicate;

- communicative potential, including such characteristics as a person's appearance, prestige, position in the microgroup, age, state of health, etc.;

- ability to recognize people;

- ability to critically evaluate the created pedagogical situation and take an adequate position in relation to it;

- ability to predict behaviour;

- ability to model the possibilities of dialogic communication in its various manifestations;

- ability to actively listen;

- ability to argue;

- ability to cooperate;

- ability to prove, convince;

- ability to logically evaluate their actions.

The emotional-heuristic communicative and creative abilities include:

- developed perception and intuition; 
- developed empathy, which is defined as an understanding of the emotional state of another person in the form of empathy. In the creative aspect, empathy is manifested in the fact that the teacher, preparing for a lesson or extra-curricular activity, takes the position of students and selects material that is interesting to students, anticipating difficulties and possible help on their part;

- pedagogical artistry. This is primarily a vivid, expressive embodiment of their own feelings, their spiritual state, their sincere love for children. For this, a teacher needs a pleasant voice, mastery of various intonation transitions, expressive facial expressions and gestures, subtle humour, which is an indicator of the extraordinary intelligence and culture of the person;

- ability to adequately transmit and perceive emotions;

- ability for non-verbal self-expression;

- sense of humour;

- emotional stability;

- ability to reflectively control the individual self, that is, the ability to operational self-esteem and behaviour, instant correction, change in position. Reflection makes it possible for a social pedagogue to take an appropriate position for the situation, choose the appropriate tone and pace of activity, reduce and facilitate the path to the goal of communication, avoid communication barriers, promote dialogue and mutual understanding.

So, communication is an important aspect of people life, without which their existence, pleasure and regulation of needs, socialization are impossible.

For the professional activities of a social pedagogue and social worker, it is necessary to have theoretical knowledge, professional skills and speech culture skills, that is to have communicative competence.

The specific nature of the professional activities of a social pedagogue necessitates fluency in the language as a means of communication for future successful professional activities.

Conclusions. Summarizing the foregoing, it can be stated that communicative competence covers knowledge, skills that are formed in the process of training.

Communicative competence is manifested in the process of solving communicative problems.

The study of the professional qualities of a social pedagogue that are significant for the effective implementation of professional activities is one of the most important tasks at the present stage of training highly qualified specialists.

The future professional activity depends on the level of communicative competence of a social pedagogue.

Communicative competence is an important component of the professional development of the future social pedagogue and one of the most important components of his professional growth.

\section{REFERENCES}

1. Amelina S. Humanistic foundations of the formation of professional communication culture: history, present, prospects / S. Amelina // Educational management: problems of theory and practice: monograph /T.O. Doronina, S.N. Amelina, V.V. Gamanyuk et al.]: Ed. T.A. Doronina. - Kryviy Rih: VNP Interservice LLC, 2014. - 300 p.

2. Higher education in Ukraine and the Bologna process: textbook / edited by V. Flint. Group of authors: M.F. Stepko, Ya.Ya. Bolyubash, V.D. Shynkaruk, V.V. Grubinko, I.I. Babiy. - Kiev: Education, 2004. - 384 p.

3. Bulletin of Glukhov State Pedagogical University. A series of pedagogical sciences. Issue 15. Part II Glukhov: GNPU named after A. Dovzhenko, 2010 .-- 187 p. 12-16

4. Zabrotskyi M.M. The communicative competence of a teacher: the essence and ways of formation / M.M. Zabrotskyi, S.D. Maksimenko. - Kyiv-Zhytomyr: Volyn, 2000. -- 112 p.

5. Winter I.Ya. Pedagogical Psychology: a textbook for high schools / I.Ya. Zima. - Moscow: Publishing. Logos Corporation, 2000. - 384 p.

6. Kaydalova L.G. Psychology of communication: [study guide] / L.G. Kaydalova, L.V. Plyaka. - Kharkov: NFaU, 2011. -- 132 p.

7. Orban-Lembrick L.E. Psychology of professional communication: a training manual / L.E. OrbanLembrick. - Chernivtsi: Books - XXI, 2010. -- 528 p.

8. Petrovska L.A. Competence in communication. Socio-psychological training / L.A. Petrovska. - Moscow, 1989. -- S. 78-79.

9. $\quad$ Pedagogical skill: textbook / I.A. Zyazyun, L. Kramuschenko, I.F. Krivonos et al.; Edited by I.A. Zyazyun. - Kyiv: Higher School, 2004. - 422 p.

10. Razmolodchykova I. Professional communication is an important precondition for the professional activity of a future social pedagogue / I. Razmolodchykova // Social and Economic aspects of Education in Modern Society. - Vol.1, April 22, 2019, Warsaw, Poland. - 15-20. 